\title{
Çevre Bilincinin Yeşil Yıldızlı Otel Tercihine Etkisi: ESOGÜ Turizm Fakültesi Öğrencileri Örneği
}

\begin{abstract}
Çevre Bilincinin Yeşil Yıldızlı Otel Tercihine Etkisi: ESOGÜ Turizm Fakültesi Öğrencileri Örneği

Öz

$\mathrm{Bu}$ araştırma çevresel duyarlılık, çevresel tutum ve çevresel davranışın yeşil yıldızı otel tercihine olan etkilerinin belirlenmesi amacıyla yapılmıştır. Bu kapsamda öncelikle çevresel duyarlılık, çevresel tutum, çevresel davranış ve yeşil yıldızlı otel kavramları açıklanmış ve ilgili çalışmalar derlenmiştir. Modeldeki yapısal ilişkilerin sınanmasında kullanılan veriler Eskişehir Osmangazi Üniversitesi Turizm Fakültesi öğrencilerine ( $n=323)$ yüz yüze bir anket yapılarak elde edilmiştir. Araştırmanın devamında, içsel gizil değişken olarak yeşil yıldızlı otel tercihi ve dışsal gizil değişkenlerin de çevresel duyarlıık, çevresel tutum ve çevresel davranış olarak betimlendiği bir yapısal eşitlik modeli kurulmuştur. Araştırma sonucunda; çevresel duyarlılık, çevresel tutum ve çevresel davranışın yeşil yıldızlı otel tercih niyeti arasında istatistiksel olarak anlamlı bir ilişki olduğu tespit edilmiştir.
\end{abstract}

Anahtar Kelimeler: Çevresel Duyarlılık, Çevresel Tutum, Çevresel Davranış, Yeşil Yıldızlı Otel, Yapısal Eşitlik Modellemesi.
Yasin Emre Oğuz ${ }^{1}$

Veysel Yılmaz ${ }^{2}$

\begin{abstract}
The Impact of Environmental Consciousness on the Selection of Green Star Hotel: Case of ESOGU Tourism Faculty Students
\end{abstract}

\section{Abstract}

This study aims to determine the effects of environmental sensitivity, environmental attitude and environmental behavior on green star hotel preference. In this context, environmental sensitivity, environmental attitude, environmental behavior and green star hotel concepts are explained based on the literature. Data which is used in order to test the structural relationship between the variables are collected from Eskisehir Osmangazi University Faculty of Tourism students through a face to face survey method $(n=323)$. This study proposes a structural equality model which defines green star hotel preference as the endogenous latent variable and environmental sensitivity, environmental attitude and environmental behavior as the exogenous latent variable. Results indicate that there is a statistically significant correlation between environmental awareness, environmental attitude, environmental behavior and green star hotel preference.

Keywords: Environmental Sensitivity, Environmental Attitude, Environmental Behavior, Green Star Hotel, Structrual Equation Modeling.

\section{Giriş}

1970'li yıllarla birlikte çevre bilinci ve sürdürülebilirlik olguları giderek önem kazanmaya başlayan kavramlar haline gelmiştir (Dünya Çevre ve Kalkınma Komisyonu, 1987). Özellikle küresel ısınma, doğal kaynakların tükenmesi, çevrenin kirlenmesi gibi tüm insanlığı etkileyen küresel problemler bilinçli bir toplum kesiminin de ortaya çıkmasını sağlamıştır (Atabey ve Yokaş, 2016). Bu bilinçli toplum hayatlarının her alanında olduğu gibi yeşil ürün olarak kabul tüketim ürünlerine yönelik olarak yapılmaktadır. Bu araştırmada ise lüks bir mal olarak kabul edilen turistik ürün üzerine incelemeler yapılmıştır. Bu durum araştırmanın özgün değerini oluşturmaktadır. Buradan hareketle araştırmanın amacı; öğrencilerin çevresel duyarlılık,

\footnotetext{
${ }^{1}$ Arş. Gör., Eskişehir Osmangazi Üniversitesi, Turizm Fakültesi, Turizm İşletmeciliği Bölümü. yeoguz@ogu.edu.tr, yazar ORCID bilgisi: https://orcid.org/0000-0002-2139-4278.

2 Prof. Dr., Eskişehir Osmangazi Üniversitesi, Fen Edebiyat Fakültesi, İstatistik Bölümü. vyilmaz@ogu.edu.tr, yazar ORCID bilgisi: https://orcid.org/0000-0002-3249-8961.
} 
çevresel tutum ve çevresel davranış algılarının yeşil yıldızlı otel tercih niyetine olan etkilerinin incelenmesi olarak belirlenmiş ve literatüre katkı sağlanmaya çalışılmıştır.

\section{Kavramsal Çerçeve}

Araştırma kapsamında çevre bilincinin alt boyutları olan çevresel duyarlılık, çevresel tutum ve çevresel davranış ile yeşil yıldızlı otellerle ilgili açıklamalar yapılmış, bu kavramlarla ilgili yapılan çalışmalar derlenmiş ve incelemeye tabi tutulmuştur.

\section{1. Çevre Bilinci}

Artan rekabet ve kitlesel üretim Dünya'daki kaynakların daha hızlı tüketilmesine ve çevresel kirliliğe neden olmuştur. 1970'li yıllar ile birlikte bu duruma çözüm arayışları da hızlanmıştır. Birleşmiş Millet Dünya Çevre ve Kalkınma Komisyonu tarafından 1987 yılında sunulan rapor ile birlikte sürdürülebilir kalkınma kavramı ortaya çıkmıştır. Rapor kapsamında ekonomik büyümenin yanında çevreyi korumaya yönelik politikalar da ele alınmıştır (Bayraktutan ve Uçak, 2011). Sürdürülebilirlik ile birlikte önemi daha da anlaşılan çevre bilinci kavramı akademik çalışmalara da konu olmaya başlamıştır. Bu araştırmada da çevre bilincinin alt boyutları olarak kullanılan çevresel duyarlılık, çevresel tutum ve çevresel davranış ile satın alma davranışı üzerine yapılan çalışmalar derlenmiş ve açıklanmıştır. (Ayyıldız ve Genç, 2008; Çabuk, Nakıboğlu ve Keleş, 2008; Aracıoğlu ve Tatlıdil, 2009; Yılmaz, Çelik ve Yağızer, 2009; Yılmaz ve Arslan, 2011; Kang, Stein, Heo ve Lee, 2012; Karaca, 2013; Kızıloğlu, Kızılaslan ve Gökçe, 2013; Aslan ve Çınar, 2015; Çetinkaya ve Özceylan, 2017).

Ayyıldız ve Genç (2008) tarafından yapılan araştırmada yeşil pazarlama kavramının geleneksel pazarlama anlayışından farklılıkları ve çevresel duyarlılık ile yeşil pazarlama arasındaki ilişki ele alınmıştır. Bu kapsamda araştırma örneklemi olarak belirlenen 155 öğrenciye anket uygulanmıştır. Araştırma sonucunda, katılımcıların çevresel duyarlııı̆ının ve yeşil pazarlama konusundaki düşüncelerinin olumlu yönde olduğu görülmüştür. Ancak katılımcıların bu davranışlarının sürekli ve sistemli olarak değil zaman zaman ortaya çıkan davranışlar olduğu tespit edilmiştir.

Çabuk, Nakıboğlu ve Keleş (2008) tarafından tüketicilerin sosyo-demografik özellikleri ile yeşil satın alma davranışları arasındaki ilişki incelenmiştir. Bu kapsamda 600 katılımcıya anket uygulanmıştır. Araştırma sonucunda, sosyo-demografik özellikler ve yeşil satın alma davranışları arasından istatistiksel olarak anlamlı farklılıklar tespit edilmiştir. Bu farklılıkların özellikle kadınlar, evliler, gençler, eğitimliler ve yüksek gelir seviyesine sahip katılımcılardan kaynaklandığı görülmektedir.

Aracıoğlu ve Tatlıdil (2009) tarafından yapılan araştırmada, tüketicilerin çevre bilinç düzeyinin satın alma davranışına olan etkisi incelenmiştir. Araştırmada veri toplama metodu olarak yüz yüze görüşme tekniğinden ve internet aracılığıyla yapılan anketlerden yararlanılmıştır. Araştırma kapsamında İzmir'de yaşayan 360 kişiye anket uygulanmıştır. Araştırma sonucunda, katılımcıların cinsiyet, gelir düzeyi ve eğitim seviyesinin çevre bilincine ve çevre bilincinin de satın alma davranışına etkisi olduğu tespit edilmiştir.

Yılmaz, Çelik ve Yağızer (2009) tarafından yapılan araştırmada, çevresel duyarlılık, çevresel tutum ve çevresel davranışın ekolojik ürün satın alma niyetine olan etkileri incelenmiştir. Bu kapsamda 250 katılımcıya anket uygulanmıştır. Araştırma sonucunda, çevresel duyarlılık, çevresel tutum ve çevresel davranışın ekolojik ürün satın alma niyetini istatistiksel olarak anlamlı şekilde etkilediği tespit edilmiştir. 
Yılmaz ve Arslan (2011) tarafından yapılan araştırmada, katılımcıların çevresel duyarlılıkları, çevreyi koruma vaatleri ve çevre dostu tüketim davranışları ile sosyo-demografik özellikleri arasındaki ilişkiler incelenmiştir. Araştırmanın örneklemi 477 Eskişehir Osmangazi Üniversitesi öğrencisinden oluşmaktadır. Araştırma sonucunda katılımcıların cinsiyetlerinin, ailelerinin yaşadıkları yerlerin ve annelerinin eğitim durumunun çevresel duyarlılıklarını ve çevresel davranışlarını etkilediği tespit edilmiştir. Ayrıca katılımcıların çevresel duyarlılıklarının yüksek düzeyde, çevre dostu satın alma davranışlarının orta düzeyde olduğu görülmüştür.

Kang, Stein, Heo ve Lee (2012) tarafından, otel misafirlerinin çevreci ve sürdürülebilir uygulamalar için daha fazla ödeme yapma istekliliklerinin ölçülmesi amacıyla bir araştırma yapılmıştır. Araştırma kapsamında 455 katılımcıya anket uygulanmıştır. Araştırma sonucunda, çevresel duyarlılık algısı yüksek olan katılımcıların otellerdeki yeşil uygulamalar için daha fazla ödeme yapmaya istekli oldukları tespit edilmiştir.

Karaca (2013) tarafından katılımcıların çevre bilinci ve çevreye duyarlı ürünleri kullanma eğiliminin ölçülmesi amacıyla bir araştırma yapılmıştır. Bu kapsamda Sivas'ta yaşayan 352 katılımcıya yüz yüze anket uygulanmıştır. Araştırma sonucunda katılımcıların çevre bilincinin yüksek olduğu ve çevreye duyarlı ürünleri kullanma eğiliminde oldukları tespit edilmiştir.

Kızıloğlu, Kızılaslan ve Gökçe (2013) tarafından üniversite öğrencilerinin yeşil gıda ürünleri hakkında bilgi, görüş ve tutumlarının belirlenmesi amacıyla bir araştırma yapılmıştır. İlgili araştırmanın bir diğer amacı da, öğrencilerin yeşil ürün tüketimi için daha fazla ödeme yapma istekliliklerinin incelenmesi olarak belirlenmiştir. Bu kapsamda 238 üniversite öğrencisine anket uygulanmıştır. Araştırma sonucunda, katılımcıların yeşil gıda ürünlerine karşı tutumlarının; beslenme, sağlık, çevre bilinci ve bilinçlendirme faktörleri altında ifade edildiği belirlenmiştir. Ayrıca katılımcıların çevreyi ve sağlıklarını koruma istekliliklerinin yüksek olduğu tespit edilmiştir.

Aslan ve Çınar (2015) tarafından yapılan araştırmada, çevresel duyarlılık algısının yeşil ürün satın alma niyetine etkisi incelenmiştir. Bu kapsamda 400 katılımcıya anket uygulanmıştır. Araştırma sonucunda, katılımcıların yeşil pazarlama faaliyetleriyle ilgili yeterli bilgiye sahip olmadıkları ve bu nedenle yeşil ürün satın alma konusunda kararsız oldukları görülmüştür.

Çetinkaya ve Özceylan (2017) tarafından Gaziantep Üniversitesi öğrencilerine yönelik bir araştırma yapılmıştır. Araştırmanın amacı, yeni nesil tüketicileri olarak kabul edilen gençlerin çevresel duyarlılık ve yeşil ürün satın alma tutumlarının incelenmesi olarak belirlenmiştir. Buradan hareketle 380 üniversite öğrencisine anket uygulanmıştır. Araştırma sonucunda, çevresel duyarlılık ve yeşil ürün satın alma davranışı ile cinsiyet, eğitim durumu ve öğrenim gördükleri bölümler arasında istatistiksel olarak anlamlı farklılıklar olduğu tespit edilmiştir.

\subsection{Yeşil Yıldızlı Oteller}

Araştırma kapsamında incelenen diğer bir kavram da yeşil yıldızlı otellerdir. Çevrenin korunması, çevre bilincinin geliştirilmesi ve konaklama işletmelerinde çevreye duyarlı işletmecilik ile yapılaşmanın teşvik edilmesi adına otel işletmelerine 2008 yılı itibariyle yeşil yıldız verilmeye başlanmıştır (Kültür ve Turizm Bakanlığı, 2017). Araştırmanın daha önceki bölümlerinde de değindiğimiz gibi sürdürülebilirlik kavramının önem kazanması ile birlikte, üreticilerin ve tüketicilerin bu kavrama yönelik farkındalığı artmıştır. Bu durum üreticilerin "çevre dostu" veya "yeşil" ürün üretmesine, tüketicilerin de bu ürünlere yönelik satın alma davranışlarının arttırmasına neden olmuştur (Tayfun ve Öçlü, 2016; Çakır, 2017). Bu kapsamda literatür taraması yapılmış ve yeşil yıldızlı otellerle alakalı çalışmalar açıklanmıştır 
(Eldemerdash ve Mohammed, 2013; Mesci, 2014; Akova, Yaşar, Aslan ve Çetin, 2015; Giritlioğlu ve Güzel, 2015; Özer, Kement ve Gültekin, 2015; Aylan ve Sezgin, 2016; Yıldız ve Kılıç, 2016; Akandere ve Zerenler, 2017; Kement ve Çavuşoğlu, 2017).

Eldemerdash ve Mohamed (2013) tarafından Mısır'daki yeşil yıldızlı otellerle yönelik bir araştırma yapılmıştır. Illgili araştırmada, yeşil yıldızı otellerin mühendisler tarafından algılanma şekilleri incelemeye çalışılmıştır. Buradan hareketle, Mısır'da faaliyet gösteren 18 bakım mühendisiyle görüşülmüş ve yeşil yıldızlı oteller ile ilgili görüşleri alınmıştır. Araştırma sonucunda, çevre ve mali külfetler, insan kaynaklarının bilgi ve becerileri ile ziyaretçilerin tutumlarıyla ilgili engeller tespit edilmiş ve çözüm önerilerinde bulunulmuştur.

Mesci (2014) tarafından yapılan araştırmada, çevreye duyarlı uygulamalarla hizmet veren diğer bir ifadeyle yeşil yıldızlı otel işletmelerinin ülke ekonomisine olan katkılarını incelenmiştir. Araştırma verilerin toplanmasında nitel yöntemlerden yararlanılmıştır. Bu kapsamda yeşil yıldızlı otellerle ilgili dokümanlar incelemeye tabi tutulmuştur. Araştırma sonucunda, yeşil yıldızlı otellerin hem tasarruf sağlama hem de kaynakların daha verimli kullanılmasına katkı sağladığına ulaşılmıştır.

Akova, Yaşar, Aslan ve Çetin (2015) tarafından İstanbul'da faaliyet gösteren, yeşil yıldıza sahip dört ve beş yıldızlı otellerde çalışanların adhokrasi, klan, bürokrasi ve pazar gibi örgüt kültürü tipleri ve çevre yönetimi algıları arasındaki ilişkiler incelenmiştir. Araştırma kapsamında İstanbul'da faaliyet gösteren 22 yeşil yıldızlı otele gidilmiş ve örneklem olarak belirlenen 221 katılımcıya anket uygulanmıştır. Araştırma sonucunda, yeşil yıldızlı otellerin genel olarak pazar kültürünü benimsedikleri ve çevre yönetimiyle ilgili en olumlu algıya sahip olanların klan kültürü tipine sahip kişiler olduğu görülmüştür.

Giritlioğlu ve Güzel (2015) tarafından Gaziantep ve Hatay illerinde faaliyet gösteren üç, dört ve beş yıldızlı otellerin yeşil yıldız kriterlerini uygulama düzeylerinin belirlenmesi ve yeşil yıldız uygulamalarında otellerin statüleri ve hizmet ettikleri şehirlere göre farklılık gösterip göstermediğinin tespit edilmesi amacıyla bir araştırma yapılmıştır. Araştırma verilerinin toplanmasında anket yönteminden yararlanılmıştır. Araştırmanın örneklemini Gaziantep ve Hatay'da faaliyet gösteren otellerde yöneticilik yapan katılımcılar oluşmaktadır. Araştırma sonucunda, otellerde yeşil yıldıza yönelik uygulamaların "orta" seviyede olduğu görülmüştür. Ayrıca farklı statüdeki otellerin uygulamaları arasında belirgin farklılıklar olduğu tespit edilmiştir. Bu farklıığın özellikle üç yıldızlı otellerden kaynaklandığı görülmüştür.

Özer, Kement ve Gültekin (2015) tarafından yapılan araştırmada, planlanmış davranış modelinin genişletilmiş hali kullanılarak yeşil yıldızlı otelleri ziyaret edenlerin bu işletmeleri tekrar ziyaret niyetleri incelenmiştir. Bu kapsamda yeşil yıldızlı otellerde konaklama yapan 284 müşteriye anket uygulanmıştır. Araştırmada analiz yöntemi olarak yapısal eşitlik modellemesi kullanılmıştır. Araştırma sonucunda hizmet kalitesi ve sübjektif normun tekrar ziyaret niyetini olumlu yönde etkilediği tespit edilmiştir. Diğer taraftan, tutum ve algılanan davranışsal kontrolün tekrar ziyaret niyeti üzerine istatistiksel olarak anlamlı bir etkisi olmadığı görülmüştür.

Aylan ve Sezgin (2016) tarafından otel müşterilerinin yeşil yıldızı otellere yönelik düşüncelerinin ve konaklama niyetlerinin demografik özelliklere göre farlılık gösterip göstermediğinin incelenmesi amacıyla bir araştırma yapılmıştır. Araştırmanın evrenini, Antalya'da faaliyet gösteren yeşil yıldıza sahip beş yıldızlı konaklama işletmelerinde konaklayan müşteriler oluşturmaktadır. Araştırmada veri toplama yöntemi olarak anket 
kullanılmıştır. Araştırma sonucunda, müşterilerin yeşil yıldızlı otellerde kalma niyetlerinin yaş, cinsiyet, gelir durumu, eğitim seviyesi, meslek, medeni durum ve konaklama sıklığına göre istatistiksel olarak anlamlı bir farklılık olduğu görülmüştür.

Yıldız ve Kılıç (2016) tarafından yapılan araştırmada, Alman turistlerin çevre bilinci ve çevre dostu otel algısının davranışsal niyetler üzerine etkileri incelenmiştir. Bu kapsamda, Antalya'yı ziyaret eden Alman turistlere anket uygulanmıştır. Araştırmanın örneklemi 360 Alman turistten oluşmaktadır. Yapılan regresyon analizi sonucunda, turistlerin çevre dostu otel algısının ve çevre bilincinin davranışsal niyetleri arasından istatistiksel olarak anlamlı bir ilişki tespit edilmiştir.

Akandere ve Zerenler (2017) tarafından yeşil yıldızlı konaklama işletmelerinde yöneticilerin yeşil tedarik zinciri yönetimi kararlarını baskılayan iç ve dış faktörlerin, işletme performansına etkilerini belirlenmesi amacıyla bir araştırma yapılmıştır. Araştırmanın örneklemi Türkiye'de faaliyet gösteren 250 yeşil yıldızlı otelden oluşmaktadır. Araştırma sonucunda, yeşil tedarik zinciri yönetimini baskılayan iç ve dış faktörlerin işletme performansını istatistiksel olarak anlamlı ve pozitif yönde etkilediği görülmüştür.

Kement ve Çavuşoğlu (2017) tarafından yapılan araştırmada, yeşil yıldızlı otelleri ziyaret edenlerin hafızaya dayalı deneyimlerinin anılarına ve sadakatlerine etkileri belirlenmeye çalışılmıştır. Araştırma verilerinin toplanmasında anket formundan yararlanılmıştır. Bu kapsamda araştırma örneklemi olarak belirlenen 410 katılımcıya anket uygulanmıştır. Araştırma sonucunda yeşil yıldızı otelleri tercih eden müşterilerin estetik ve kaçış deneyimlerinin anılarını etkilediği, eğlence ve eğitim deneyimlerinin ise anılarını etkilemediği görülmüştür. Araştırmanın diğer bir sonucu da, müşterilerin yeşil yıldızlı otellerde edinmiş oldukları anıların sadakatlerini istatistiksel olarak anlamlı ve pozitif yönde etkilediğidir.

\section{Yöntem}

\subsection{Yapısal Eşitlik Modellemesi}

Araştırmada çevresel duyarlııı, çevresel tutum ve çevresel davranışının yeşil yıldızlı otel tercih niyetine olan etkilerinin incelenmesi amaçlanmıştır. Bu amaçla değişkenler arasındaki nedensel ilişkilerin ortaya konulmasını sağlayan ve kurulan modelin çeşitli uyum ölçütleriyle incelenmesine imkân veren yapısal eşitlik modellemesinin kullanılmasına karar verilmiştir. Genel anlamda Yapısal Eşitlik Modellemesi, gizil değişkenler arasında neden-sonuç ilişkisinin var olduğu ve bu gizil değişkenlerin gözlenen değişkenler aracılığıyla ölçülebileceği varsayımına dayanan çok değişkenli istatistiksel bir yöntem olarak tanımlanmaktadır (Yılmaz, 2016).

\subsection{Araştırma Evreni ve Örneklemi}

Araştırmanın evreni 2017 - 2018 eğitim öğretim döneminde Eskişehir Osmangazi Üniversitesi Turizm Fakültesinde 4 yıllık lisans eğitimi almakta olan 821 kayıtlı öğrenciden oluşmaktadır. Araştırmada örneklem olarak ESOGÜ Turizm Fakültesi öğrencilerinin seçilmesinin temelinde yeşil yıldızlı otel kavramının ülkemiz açısından çok fazla bilinmeyen yeni bir kavram olması yatmaktadır. Evrende yer alan tüm öğrencilere ulaşmak zaman, maliyet ve ulaşılabilirlik açısından mümkün olmadığından örneklem seçilmesine karar verilmiştir. Belirli evren büyüklükleri için tahmini örneklem verileri dikkate alındığında araştırma örnekleminin \%95 güven aralığında ve 0,05 hata payında en az 278 kişiden oluşması gerekmektedir (Cohen, Manion ve Morrison, 2000). Bu kapsamda rassal olarak seçilen 323 katılımcıya Aralık 2017 - Şubat 2018 dönemi arasında yüz yüze görüşerek anket uygulanmıştır. 


\subsection{Verilerin Toplanması}

Araştırma verilerinin toplanmasında kullanılan anket formu iki bölümden oluşmaktadır. Anketin birinci bölümünde katılımcıların demografik özelliklerini belirlemeye yönelik sorular yer almaktadır. Anketin ikinci bölümünde ise çevresel duyarlılık, çevresel tutum, çevresel davranış ve yeşil yıldızlı otel tercih niyetine yönelik 5'li Likert tipinde derecelendirilmiş 27 ifade bulunmaktadır (1= Kesinlikle Katılmıyorum, $2=$ Katılmıyorum, $3=\mathrm{Ne}$ Katılıyorum $\mathrm{Ne}$ Katılmıyorum, 4= Katılıyorum, 5= Kesinlikle Katılıyorum). Araştırmada kullanılan ölçek literatürde yer alan çalışmalardan derlenmiştir (Kaiser, Ranney, Hartig ve Bowler, 1999; Kaiser, Wölfing ve Fuhrer, 1999; Fraj ve Martinez, 2007; Yılmaz, Çelik ve Yağızer, 2009).

\subsection{Araştırma Modeli ve Hipotezler}

Araştırmada çevresel duyarlılık, çevresel tutum ve çevresel davranış algılarının yeşil yıldızlı otel tercihine olan etkilerinin incelendiği araştırma modeli Şekil 1'de verilmiştir.

\section{Şekil 1: Araştırma Modeli}

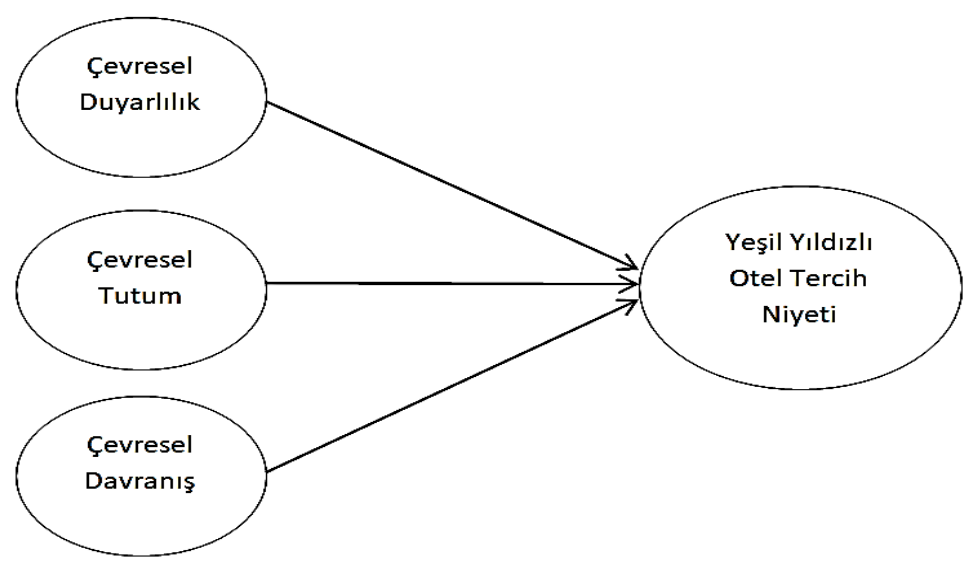

Şekil 1'de verilen yapısal modelden yararlanılarak aşağıdaki yer alan hipotezler kurulmuştur:

$\mathbf{H}_{1}$ : Çevresel duyarlıık ile yeşil yıldızlı otel tercihi arasında istatistiksel olarak anlamlı bir ilişki vardır.

$\mathbf{H}_{2}$ : Çevresel tutum ile yeşil yıldızlı otel tercihi arasında istatistiksel olarak anlamlı bir ilişki vardır.

$\mathbf{H}_{3}$ : Çevresel davranış ile yeşil yıldızlı otel tercihi arasında istatistiksel olarak anlamlı bir ilişki vardır. 


\section{Bulgular}

\subsection{Katılımcıların Demografik Özelliklerine iliş̧kin Bulgular}

Analizin ilk aşamasında katılımcıların cinsiyet, öğrenim süresi, yaş, gelir, anne eğitim durumu ve baba eğitim durumu gibi demografik özelliklerine ilişkin bulgular tablolaştırılmış ve yorumlanmıştır.

Tablo 1: Katılımcıların Cinsiyetlerine Göre Dağılımları

\begin{tabular}{lrr}
\hline Cinsiyet & Sayı & Yüzde (\%) \\
\hline Kadın & 160 & 49,5 \\
Erkek & 163 & 50,5 \\
\hline Toplam & $\mathbf{3 2 3}$ & $\mathbf{1 0 0}$ \\
\hline
\end{tabular}

Tablo 1'de araştırma katılanların cinsiyetlerine göre dağılımları yer almaktadır. Buna göre katılımcıların \%49,5’i (160) kız öğrencilerden, \%50,5’i (163) erkek öğrencilerden oluşmaktadır.

Tablo 2: Katılımcıların Öğrenim Sürelerine Göre Dağılımları

\begin{tabular}{lrr}
\hline Öğrenim Süresi & Sayı & Yüzde (\%) \\
\hline 1 Yıl & 62 & 19,2 \\
2 Yıl & 68 & 21,1 \\
3 Yıl & 83 & 25,7 \\
4 Yıl & 65 & 20,1 \\
5 Yıl ve Üzeri & 45 & 13,9 \\
\hline Toplam & $\mathbf{3 2 3}$ & $\mathbf{1 0 0}$ \\
\hline
\end{tabular}

Tablo 2'ye göre araştırmaya katılanların \%25,7'si (83) 3 yıldır, \%21,1'i (68) 2 yıldır, \%20,1'i (65) 4 yıldır, \%19,2'si (62) 1 yıldır ve \%13,9'u (45) 5 yıl ve daha uzun zamandır ESOGÜ Turizm Fakültesi'nde öğrenim görmektedir.

Tablo 3: Katılımcıların Yaşlarına Göre Dağılımları

\begin{tabular}{lrr}
\hline Yaş & Sayı & Yüzde (\%) \\
\hline $18-19$ Yaş & 64 & 19,8 \\
$20-21$ Yaş & 80 & 24,8 \\
$22-23$ Yaş & 96 & 29,7 \\
$24-25$ Yaş & 67 & 20,7 \\
26 Yaş ve Üzeri & 16 & 5,0 \\
\hline Toplam & $\mathbf{3 2 3}$ & $\mathbf{1 0 0}$ \\
\hline
\end{tabular}

Tablo 3'e göre katılımcıların; \%29,7'si (96) $22-23$ yaş arasında, \%24,8'i (80) $20-21$ yaş arasında, \%20,7'si (67) $24-25$ yaş arasında, \%19,8'i (64) 18 - 19 yaş arasında ve \%5'i (16) 26 yaş ve üstünde olarak tespit edilmiştir.

Tablo 4: Katılımcıların Gelirlerine Göre Dağılımları

\begin{tabular}{lrr}
\hline Gelir & Sayı & Yüzde (\%) \\
\hline $0-499 T L$ & 94 & 29,1 \\
$500-999 T L$ & 70 & 21,7 \\
$1000-1499 T L$ & 61 & 18,9 \\
$1500-1999 T L$ & 52 & 16,1 \\
2000TL ve Üzeri & 46 & 14,2 \\
\hline Toplam & $\mathbf{3 2 3}$ & $\mathbf{1 0 0}$ \\
\hline
\end{tabular}

Tablo 4'e göre araştırmaya katılanların \%29,1'i (94) 0 - 499 TL arası, \%21,7'si (70) 500 999 TL arası, \%18,9'u (61) 1000 - 1499 TL arası, \%16,1'i (52) 1500 - 1999 TL arası ve \%14,2'si (46) 2000 TL ve üzeri gelire sahiptir. 
Eskişehir Osmangazi Üniversitesi ïBF Dergisi

Tablo 5: Katılımcıların Annelerinin Eğitim Durumlarına Göre Dağılımları

\begin{tabular}{lrr}
\hline Eğitim Durumu & Sayı & Yüzde (\%) \\
\hline İlkokul & 58 & 18,0 \\
Ortaokul & 59 & 18,6 \\
Lise & 116 & 35,9 \\
Üniversite & 77 & 23,8 \\
Lisansüstü & 13 & 4,0 \\
\hline Toplam & $\mathbf{3 2 3}$ & $\mathbf{1 0 0}$ \\
\hline
\end{tabular}

Araştırmaya katılanların annelerinin eğitim durumlarına yönelik bulgular Tablo 5 'te verilmiştir. Buna göre; \%35,9'unun (116) annesi lise mezunu, \%23,8'inin (77) annesi üniversite mezunu, \%18,6'sının (59) annesi ortaokul mezunu, \%18,0'ının (58) annesi ilkokul mezunu ve $\% 4,0$ ’ının (13) annesi lisansüstü mezunudur.

Tablo 6: Katılımcıların Babalarının Eğitim Durumlarına Göre Dağılımları

\begin{tabular}{lrr}
\hline Eğitim Durumu & Sayı & Yüzde (\%) \\
\hline İlkokul & 48 & 14,9 \\
Ortaokul & 55 & 17,0 \\
Lise & 116 & 35,9 \\
Üniversite & 84 & 26,0 \\
Lisansüstü & 20 & 6,2 \\
\hline Toplam & $\mathbf{3 2 3}$ & $\mathbf{1 0 0}$ \\
\hline
\end{tabular}

Araştırmaya katılanların babalarının eğitim durumlarına yönelik bulgular Tablo 6 'da verilmiştir. Buna göre; \%35,9'unun (116) babası lise mezunu, \%26,0'ının (84) babası üniversite mezunu, \%17,0'ının (55) babası ortaokul mezunu \%14,9'unun (48) babası ilkokul mezunu ve $\% 6,2$ 'sinin (14) babası lisansüstü mezunudur.

\subsection{Geçerlilik ve Güvenilirlik Bulguları}

Araştırmada toplanan verilerin geçerlilik ve güvenilirliği analizin en önemli aşamalarından biri olarak kabul edilmektedir. Güvenirlik kavramı her ölçüm için geçerlidir. Güvenilirlik kullanılan ölçeğin tutarlılığını ve incelenen sorunu ne derecede ölçtüğünü göstermektedir (Kalaycl, 2010: 403).

Tablo 7: Güvenilirlik Analizi Bulguları

\begin{tabular}{cccc}
\hline iFADELER & ORTALAMA & STANDART HATA & $\begin{array}{c}\text { CRONBACH'S ALPHA } \\
\text { (ÇIKARTILDIĞINDA) }\end{array}$ \\
\hline 1 & 4,2322 & 1,08288 & 0,933 \\
2 & 4,2879 & 1,00654 & 0,933 \\
3 & 4,1796 & 1,02391 & 0,933 \\
4 & 4,0929 & 0,97359 & 0,933 \\
5 & 4,1610 & 1,02701 & 0,933 \\
6 & 4,2848 & 0,97132 & 0,933 \\
7 & 4,3158 & 0,94539 & 0,933 \\
8 & 4,0000 & 1,00000 & 0,933 \\
9 & 4,1579 & 0,99836 & 0,934 \\
10 & 3,8019 & 1,07096 & 0,933 \\
11 & 4,0341 & 1,04052 & 0,933 \\
12 & 4,1300 & 1,00084 & 0,932 \\
13 & 4,1548 & 1,00659 & 0,933 \\
14 & 3,5418 & 0,97831 & 0,933 \\
15 & 3,6006 & 1,02980 & 0,933 \\
16 & 3,1579 & 1,04991 & 0,934 \\
17 & 3,2817 & 1,11645 & 0,934 \\
\hline
\end{tabular}




\begin{tabular}{cccc}
\hline 18 & 2,9257 & 1,28321 & 0,935 \\
19 & 2,8483 & 1,30879 & 0,937 \\
20 & 2,7245 & 1,29557 & 0,937 \\
21 & 3,0031 & 1,21456 & 0,936 \\
22 & 3,7616 & 1,11545 & 0,934 \\
23 & 3,7740 & 1,03735 & 0,933 \\
24 & 3,8452 & 1,03098 & 0,933 \\
25 & 3,6223 & 1,10605 & 0,933 \\
26 & 3,7307 & 1,12781 & 0,933 \\
27 & 3,2879 & 1,24639 & 0,934 \\
\hline
\end{tabular}

Yapılan güvenilirlik analizi sonucunda Cronbach's Alpha değeri 0,936 olarak tespit edilmiştir (Tablo 7).

\subsection{Açıklayıcı Faktör Analizi Bulguları}

Açıklayıcı faktör analizi çalışmalarına başlamadan önce verilerin açıklayıcı faktör analizine uygun olup olmadığına araştırmak amacıyla KMO (Kaiser-Meyer-Olkin) ve Bartlett's testleri bulguları incelenmiş olup (KMO: 0,932 - Bartlett's: 0,00 ve $p<0,01$ ) iki değerin de faktör analizine uygun olduğu saptanmıştır.

Tablo 8: Açıklayıcı Faktör Analizi Bulguları

\begin{tabular}{|c|c|c|c|c|}
\hline IFADELER & $\begin{array}{l}\text { Faktör } \\
\text { Yükü }\end{array}$ & $\begin{array}{l}\text { Açılanan } \\
\text { Varyans \% }\end{array}$ & $\begin{array}{c}\text { Faktör } \\
\text { Güvenilirliği }\end{array}$ & Özdeğer \\
\hline \multicolumn{5}{|l|}{ Çevresel Duyarlılık } \\
\hline Küresel ısınmanın büyük bir sorun haline geldiğini düşünüyorum. & 0,800 & 39,839 & 0,922 & 10,757 \\
\hline $\begin{array}{l}\text { Ozon tabakasının delinmesinin çevresel bir sorun olduğunu } \\
\text { düşünüyorum. }\end{array}$ & 0,798 & & & \\
\hline Kirliliğin birçok türünün tehlikeli seviyelere yükseldiğini düşünüyorum. & 0,793 & & & \\
\hline Bazı canlı türlerinin yok olma tehdidi altında olduğunu düşünüyorum. & 0,769 & & & \\
\hline $\begin{array}{l}\text { Gelecekte temiz su kaynaklarına ulaşmanın bir sorun haline geleceğini } \\
\text { düşünüyorum. }\end{array}$ & 0,769 & & & \\
\hline $\begin{array}{l}\text { Bazı önemli kaynaklarda yaşanacak kıtlığın yakın zamanda } \\
\text { gerçekleşeceğini düşünüyorum. }\end{array}$ & 0,727 & & & \\
\hline $\begin{array}{l}\text { Tarımda kimyasal madde kullanılmasının çevreye zarar verdiğini } \\
\text { düşünüyorum. }\end{array}$ & 0,727 & & & \\
\hline Çevre hakkında çok endişeliyim. & 0,594 & & & \\
\hline \multicolumn{5}{|l|}{ Çevresel Tutum } \\
\hline $\begin{array}{l}\text { Doğal çevreyi korumak için siyasi girişimlerin yapılması gerektiğini } \\
\text { düşünüyorum. }\end{array}$ & 0,744 & 13,948 & 0,812 & 3,766 \\
\hline $\begin{array}{l}\text { Kirliliği önlemek için çıkarılmış yasaların kararlılıkla uygulanması } \\
\text { gerektiğini düşünüyorum. }\end{array}$ & 0,718 & & & \\
\hline $\begin{array}{l}\text { Doğal çevreyi korumak için toplumsal girişimlerin yapılması gerektiğini } \\
\text { düşünüyorum. }\end{array}$ & 0,714 & & & \\
\hline $\begin{array}{l}\text { Çevrenin korunmasına yardımcı olmak için tüketim alışkanlıklarımı } \\
\text { değiştirmeye istekliyim. }\end{array}$ & 0,701 & & & \\
\hline Mümkün olduğunca çevre dostu ürünler satın alıyorum. & 0,696 & & & \\
\hline İnsanların çevreyi ciddi bir şekilde istismar ettiğini düşünüyorum. & 0,694 & & & \\
\hline $\begin{array}{l}\text { Mümkün olduğunca ürettiğim çöpleri azaltmak için girişimlerde } \\
\text { bulunuyorum. }\end{array}$ & 0,659 & & & \\
\hline \multicolumn{5}{|l|}{ Çevresel Davranış } \\
\hline Çevreyle alakalı dergilere üye olmak gerektiğini düşünüyorum. & 0,873 & 5,701 & 0,864 & 1,539 \\
\hline Çevre örgütlerine bağış yapmanın önemli olduğunu düşünüyorum. & 0,870 & & & \\
\hline
\end{tabular}


Eskişehir Osmangazi Üniversitesi ïBF Dergisi

Çevreyle alakalı örgütlere üye olmanın önemli olduğunu $\quad 0,816$ düşünüyorum.

Çevresel meselelerle alakalı siyasi bir temsilciyle görüşmek istiyorum.

Mümkün olduğunca geri dönüştürülmüş malzemelerden yapılmış ürünleri kullanıyorum.

Mümkün olduğunca organik yiyecekler satın alıyorum.

Yeşil Yıldızlı Otel Tercih Niyet

Yeşil yıldızlı otellerin diğer konaklama işletmelerine göre daha doğal ürünler sunduğunu düşünüyorum.

Yeşil yıldızlı otellerin diğer konaklama işletmelerine göre daha sağlıklı olduğunu düşünüyorum.

Çevreyi korumak adına yeşil yıldızlı otellerde konaklamayı tercih ederim.

Gönül rahatlığıyla yeşil yıldızlı otellerde konaklamayı tercih ederim.

Yeşil yıldızlı otellerin diğer konaklama işletmelerine göre daha kaliteli hizmet sunduğunu düşünüyorum.

Diğer otellere göre daha pahalı olsa bile yeşil yıldızı otellerde konaklamayı tercih ederim.
0,729

0,646

0,583

0,849

8,140

0,909

2,198

0,804

0,795

0,794

0,761

0,675

Toplam Açıklanan Varyans

67,629

Yapılan açıklayıcı faktör analizi sonucunda dört faktör belirlenmiş ve ilgili faktörler; çevresel duyarlılık, çevresel tutum, çevresel davranış ve yeşil yıldızlı otel tercih niyeti olarak isimlendirilmiştir. Söz konusu olan dört faktörün toplam açıklanan varyansı 67,629 olarak tespit edilmiştir (Tablo 8).

\subsection{Doğrulayıcı Faktör Analizi Bulguları}

Açıklayıcı faktör analizi sonrasında, ilgili ifadelere doğrulayıcı faktör analizi yapılmıştır. Yapılan doğrulayıcı faktör analizi bulguları Şekil 2'de yer almaktadır.

\section{Şekil 2: Doğrulayıcı Faktör Analizi Bulguları}

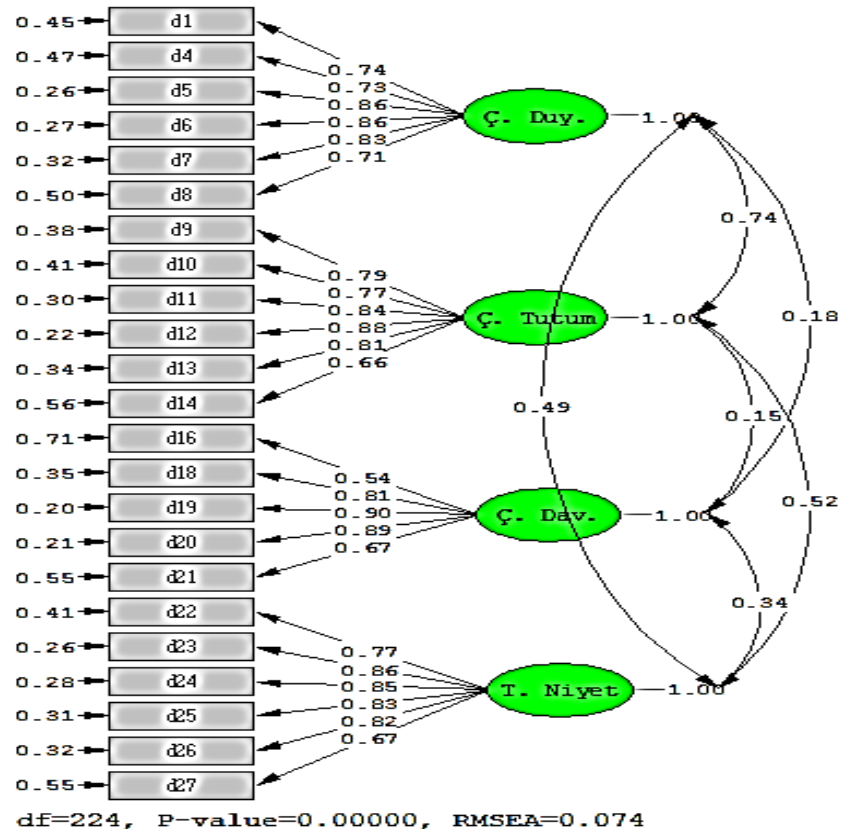


Doğrulayıcı faktör analizi sonucunda açıklayıcı faktör analizinden farklı olarak 2., 3., 15. ve 17. ifadeler faktörlerden çıkarılmıştır. Bunun temel nedeni ise RMSEA değerinin ilk doğrulayıcı faktör analizi sonucunda 0,090 çıkmış olmasıdır. Gerekli değişiklikler yapıldıktan sonra RMSEA değeri 0,074 'e düştüğünden model uyumu için bu değer kabul edilebilir olarak değerlendirilmiştir (Şekil 2).

\subsection{Yapısal Eşitlik Modellemesi Bulguları}

Doğrulayıcı faktör analizinden sonra yapısal eşitlik modellemesi aracılığıyla araştırma hipotezlerinin test edilme aşamasına geçilmiştir.

\section{Şekil 3: Yapısal Eşitlik Modellemesi Bulguları}

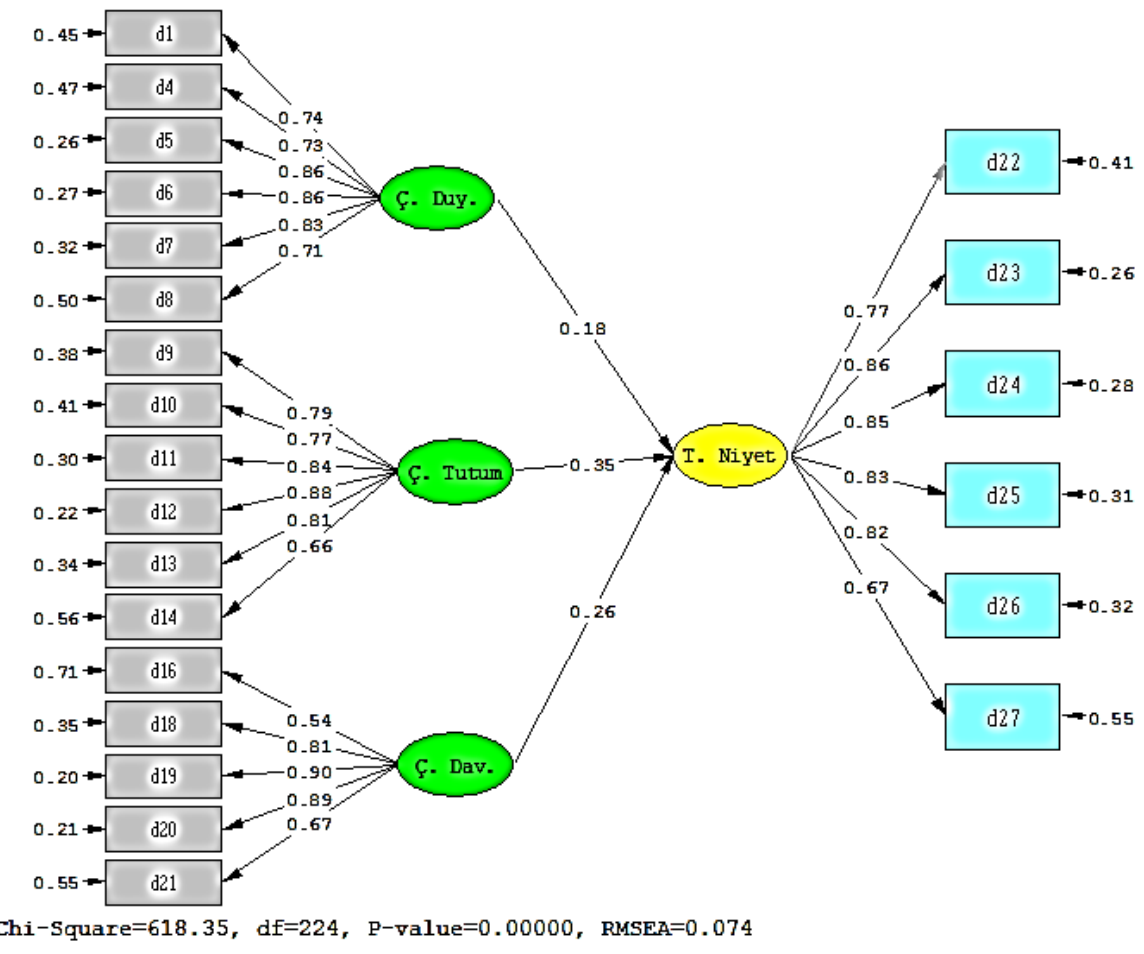

Şekil 3'te çevresel duyarlılık, çevresel tutum ve çevresel davranış bağımsız değişkenlerinin yeşil yıldızlı otel tercih niyetine olan etkisine t-değerleri üzerinden incelenmiştir. Analiz sonucunda çevresel duyarlııık, çevresel tutum ve çevresel davranışın yeşil yıldızlı otel tercih niyetine istatistiksel olarak anlamlı etkisi olduğu görülmüştür.

Analizin devamında modelin uyum değerleri, standart uyum ölçütleri ve yapı geçerliliği ile açıklanan varyans değerleri tablolar halinde verilmiş ve yorumlanmıştır. Uyum ölçütleri üzerinden yapılan değerlendirmeler araştırma kapsamında kurulan modelin geçerli olup olmadığının tespit edilmesini sağlamaktadır. 
Eskişehir Osmangazi Üniversitesi ïBß Dergisi

Tablo 9: Önerilen Modelin Uyum Değerleri ve Standart Uyum Ölçütleri

\begin{tabular}{lcccc}
\hline $\begin{array}{l}\text { Uyum } \\
\text { Ölçütleri }\end{array}$ & İyi Uyum & Kabul Edilebilir Uyum & Model Değeri & Uyum \\
\hline $\mathrm{x}^{2} / \mathrm{sd}$ & $0 \leq \mathrm{x}^{2} / \mathrm{sd}<2$ & $2 \leq \mathrm{x}^{2} / \mathrm{sd} \leq 3$ & & Kabul Edilebilir \\
$\mathrm{RMSEA}$ & $0 \leq \mathrm{RMSEA}<0,05$ & $0,05 \leq \mathrm{RMSEA} \leq 0,08$ & 0,074 & Kabul Edilebilir \\
$\mathrm{SRMR}$ & $0 \leq \mathrm{SRMR}<0,05$ & $0,05 \leq \mathrm{SRMR} \leq 0,10$ & 0,077 & Kabul Edilebilir \\
$\mathrm{NFI}$ & $0,95<\mathrm{NFI} \leq 1,00$ & $0,90 \leq \mathrm{NFI} \leq 0,95^{\mathrm{a}}$ & 0,96 & İyi Uyum \\
$\mathrm{NNFI}$ & $0,97<\mathrm{NNFI} \leq 1,00$ & $0,95 \leq \mathrm{NNFI} \leq 0,97^{\mathrm{b}}$ & 0,97 & Kabul Edilebilir \\
$\mathrm{IFI}$ & $0,95<\mathrm{IFI} \leq 1,00$ & $0,90 \leq \mathrm{IFI} \leq 0,95$ & 0,97 & İyi Uyum \\
$\mathrm{RFI}$ & $0,95<\mathrm{RFI} \leq 1,00$ & $0,90 \leq \mathrm{RFI} \leq 0,95$ & 0,95 & Kabul Edilebilir \\
$\mathrm{CFI}$ & $0,97<\mathrm{CFI} \leq 1,00$ & $0,95 \leq \mathrm{CFI} \leq 0,97$ & 0,97 & Kabul Edilebilir \\
$\mathrm{GFI}$ & $0,95<\mathrm{GFI} \leq 1,00$ & $0,90 \leq \mathrm{GFI} \leq 0,95$ & 0,86 & Kötü Uyum \\
$\mathrm{AGFI}$ & $0,90<\mathrm{AGFI} \leq 1,00$ & $0,85 \leq \mathrm{AGFI} \leq 0,90$ & 0,82 & Kötü Uyum \\
\hline
\end{tabular}

Tablo 9'da yer alan yapısal eşitlik modellemesi bulguları incelendiğinde, araştırma kapsamında kurulan modelde herhangi bir problem gözükmemektedir.

Tablo 10: Yapı Geçerliliği ve Açıklanan Varyans

\begin{tabular}{|c|c|c|c|c|c|}
\hline Faktörler / Maddeler & $\begin{array}{l}\text { Standart } \\
\text { Yükler }\end{array}$ & t-değeri & $R^{2}$ & $\begin{array}{c}\text { Yapı } \\
\text { Güvenirliliği }\end{array}$ & $\begin{array}{c}\text { Açıklanan } \\
\text { Varyans } \\
\text { (AVE) }\end{array}$ \\
\hline \multirow{7}{*}{ Çevresel Duyarlılık (ÇDU) } & & & & 0,91 & 0,63 \\
\hline & 0,88 & $11,51 * * *$ & 0,7744 & & \\
\hline & 0,83 & $11,38 * * *$ & 0,6889 & & \\
\hline & 0,84 & $11,63 * * *$ & 0,7056 & & \\
\hline & 0,70 & $9,73 * * *$ & 0,4900 & & \\
\hline & 0,76 & $10,40 * * *$ & 0,5776 & & \\
\hline & 0,72 & $9,76^{* * *}$ & 0,5184 & & \\
\hline \multirow{8}{*}{ Çevresel Tutum (ÇT) } & & & & 0,91 & 0,63 \\
\hline & 0,79 & $10,73 * * *$ & 0,6241 & & \\
\hline & 0,77 & $10,34 * * *$ & 0,5929 & & \\
\hline & 0,84 & $11,26 * * *$ & 0,7056 & & \\
\hline & 0,88 & $11,92 * * *$ & 0,7744 & & \\
\hline & 0,81 & $11,07^{* * *}$ & 0,6561 & & \\
\hline & 0,66 & $9,11 * * *$ & 0,4356 & & \\
\hline & & & & 0,88 & 0,60 \\
\hline \multirow{5}{*}{ Çevresel Davranış (ÇDA) } & 0,54 & $7,57 * * *$ & 0,2916 & & \\
\hline & 0,81 & $10,46 * * *$ & 0,6561 & & \\
\hline & 0,90 & $12,22 * * *$ & 0,8100 & & \\
\hline & 0,89 & $11,73 * * *$ & 0,7921 & & \\
\hline & 0,67 & $7,96 * * *$ & 0,4489 & & \\
\hline & & & & 0,92 & 0,64 \\
\hline & 0,77 & $10,04 * * *$ & 0,5929 & & \\
\hline Yeşil Yıldızlı Otel Tercih & 0,86 & $11,83 * * *$ & 0,7396 & & \\
\hline Niyeti & 0,86 & $11,22 * * *$ & 0,7225 & & \\
\hline \multirow[t]{3}{*}{ (YYOTN) } & 0,85 & $10,48 * * *$ & 0,6889 & & \\
\hline & 0,83 & $10,39 * * *$ & 0,6724 & & \\
\hline & 0,67 & $9,77^{* * *}$ & 0,4489 & & \\
\hline Hipotezler & & & Sonuç & & \\
\hline$H_{1}: C ̧ D U \rightarrow$ YYOTN & 0,18 & $2,15^{* *}$ & Desteklendi & & \\
\hline $\mathrm{H}_{2}: \mathrm{CT} \rightarrow \mathrm{YYOTN}$ & 0,35 & $4,08 * * *$ & Desteklendi & & \\
\hline $\mathrm{H}_{3}: C \zeta D A \rightarrow$ YYOTN & 0,26 & $4,85 * * *$ & Desteklendi & & \\
\hline
\end{tabular}


Tablo 10 incelendiğinde, araştırma kapsamında kurulan hipotezlerin $\left(\mathrm{H}_{1}, \mathrm{H}_{2}\right.$ ve $\left.\mathrm{H}_{3}\right)$ desteklendiği görülmüştür.

\section{Tartışma, Sonuç ve Öneriler}

Araştırmada çevresel duyarlılık, çevresel tutum ve çevresel davranış algılarının yeşil yıldızlı otel tercih niyetine olan etkileri yapısal eşitlik modellemesi aracılığıyla incelemeye tabi tutulmuştur. Bu kapsamda 3 adet hipotez kurulmuştur. Buna göre çevresel duyarlılık, çevresel tutum ve çevresel davranış ile yeşil yıldızlı otel tercih niyeti arasında pozitif yönlü ve istatistiksel olarak anlamlı ilişkiler tespit edilmiştir. Bu yönüyle, yapılan araştırma literatürdeki çalışmaları desteklemektedir (Ayyıldız ve Genç, 2008; Çabuk, Nakıboğlu ve Keleş, 2008; Aracıoğlu ve Tatlıdil, 2009; Yılmaz, Çelik ve Yağızer, 2009; Yılmaz ve Arslan, 2011; Kang, Stein, Heo ve Lee, 2012; Karaca, 2013; Kızıloğlu, Kızılaslan ve Gökçe, 2013; Aslan ve Çınar, 2015; Çetinkaya ve Özceylan, 2017). Araştırma sonucunda; çevresel duyarlılık algısındaki 1 birimlik artışın yeşil yıldızlı otel tercih niyetinde 0,18 birimlik, çevresel tutumdaki 1 birimlik artışın yeşil yıldızlı otel tercih niyetinde 0,35 birimlik ve çevresel davranıştaki 1 birimlik artışın yeşil yıldızlı otel tercih niyetinde 0,26 birimlik artış sağladığı tespit edilmiştir. Diğer bir ifadeyle, yeşil yıldızlı otel tercih niyetini en fazla etkileyen değişkenin çevresel tutum olduğu görülmüştür. İlgili değişkeni çevresel davranış ve çevresel duyarlılık izlemektedir. Buna göre öğrencilerin çevreye yönelik tutumlarının arttırılmasının yeşil yıldızlı otelleri tercih etme niyetlerinin de artacağı söylenebilmektedir.

Bu araştırmada ESOGÜ Turizm Fakültesi öğrencilerinin çevresel duyarlılık, çevresel tutum ve çevresel davranış algılarının yeşil yıldız otelleri tercih niyetlerine olan etkileri incelenmiştir. ileride yapılacak olan çalışmalarda, bu araştırma kapsamında kurulan yapısal eşitlik modeli doğrudan yeşil yıldızlı otelleri ziyaret edenlere uygulanarak yeni çalışmalar yapılabileceği düşünülmektedir. Ayrıca mevcut modelde yer alan çevresel duyarlılık, çevresel tutum, çevresel davranış ve yeşil yıldızlı otel tercihi değişkenlerine yeni değişkenler eklenerek yapılabilecek çalışmaların da literatüre katkı sağlayacağı düşünülmektedir. 


\section{Eskişehir Osmangazi Üniversitesi IïB Dergisi}

\section{Kaynaklar}

Akandere, Gökhan; Zerenler, Muammer (2017), “Yeşil Otellerde Yeşil Tedarik Zinciri Yönetimi ve İşletme Performansı", Uluslararası Turizm ve Sosyal Araştırmalar Dergisi, C. 1, S. 2: 77-98.

Akova, Orhan; Yaşar, Ayşe Gözde; Aslan, Ahmet; Çetin, Gürel (2015), "The Relationship Between Organizational Culture and the Environmental Management Perception of Employees: A Research on Green Star Hotels", Research Journal of Business and Management, Vol. 2 No. 2: 169-184.

Aracıoğlu, Burcu; Tatlıdil, Rezan (2009), "Tüketicilerin Satın Alma Davranışında Çevre Bilincinin Etkileri”, Ege Akademik Bakış Dergisi, C. 9, S. 2: 435-461.

Aslan, Filiz; Çınar, Recai (2015), “Yeşil Pazarlama Faaliyetleri Çerçevesinde Kafkas Üniversitesi Öğrencilerinin Çevreye Duyarlı Ürünleri Kullanma Eğilimlerini Belirlemeye Yönelik Bir Araştırma”, Kafkas Üniversitesi Iktisadi ve Idari Bilimler Fakültesi Dergisi, C. 6, S. 9: 169-184.

Atabey, Selma; Yokaş, İbrahim (2016), “Küresel Isınmanın Artış Nedenlerinin Su Kaynakları ve Turist Sağlığı Üzerindeki Yansımaları”, Akademik Bakış Dergisi, S. 54: 188-203.

Aylan, Fatmanur Kübra; Sezgin, Mete (2016), "Turistlerin Yeşil Otellere Yönelik Düşünceleri ve Kalma Niyetleri: Antalya'da Bir Araştırma", Uluslararası Turizm ve Sosyal Araştırmalar Dergisi, S: 1: 285-300.

Ayyıldız, Hasan; Genç, Kurtuluş Yılmaz. (2008), “Çevreye Duyarlı Pazarlama: Üniversite Öğrencilerinin Çevreye Duyarlı Pazarlama Uygulamaları ile Tutum ve Davranışları Üzerine Bir Araştırma”, Atatürk Üniversitesi Sosyal Bilimler Enstitüsü Dergisi, C. 12, S. 2: 505-527.

Bayraktutan, Yusuf; Uçak, Sefer (2011), “Ekolojik İktisat ve Kalkınmanın Sürdürülebilirliği”, Akademik Araştırmalar ve Çalışmalar Dergisi, C. 3, S. 4: 17-36.

Cohen, Louis; Manion, Lawrence; Morrison, Keith (2000), Research Methods in Education, London: Routledge Falmer.

Çabuk, Serap; Nakıboğlu, Burak; Keleş, Ceyda (2008), "Tüketicilerin Yeşil (Ürün) Satın Alma Davranışlarının SosyoDemografik Değişkenler Açısından İncelenmesi", Çukurova Üniversitesi Sosyal Bilimler Enstitüsü Dergisi, C. 17, S.1: 85-102.

Çakır, Musa (2017), "Yeşil Ürün Grupları Çerçevesindeki Marka ve Markalama Kararları”, Siirt Üniversitesi Sosyal Bilimler Enstitüsü Dergisi, C.5, S. 9: 333-378.

Çetinkaya, Cihan; Özceylan, Eren (2017), “Üniversite Öğrencilerinin Yeşil Satın Alma Tutumlarının İncelenmesine Yönelik Bir Araştırma: Gaziantep Üniversitesi Örneği”, Gaziantep University Journal of Social Sciences, C. 16, S. 1: 289-302.

Dünya Çevre ve Kalkınma Komisyonu (1987), http://www.un-documents.net/our-common-future.pdf, (Erişim Tarihi: 08.08.2018).

Eldemerdash, Jalian Mohamed; Mohamed, Lamiaa Moustafa. (2013), “Exploring Obstacles of Employing Environmental Practices: The Case Of Egyptian Green Hotels", Journal of Human Resources in Hospitality \& Tourism, Vol. 12, No. 3: 243-258.

Giritlioğlu, İbrahim; Güzel, Melik Onur (2015), “Otel İşletmelerinde Yeşil Yıldız Uygulamaları: Gaziantep ve Hatay Bölgesinde Bir Araştırma", Uluslararası Sosyal Araştırmalar Dergisi, C. 8, S. 40: 889-904.

Kaiser, Florian.; Ranney, Michael; Hartig, Terry; Bowler, Peter (1999), “Ecological Behavior, Environmental Attitude and Feelings of Responsibility for the Environment", European Psychologist, Vol. 4, No. 2: 59-74.

Kaiser, Florian; Wölfing, Sybille; Fuhrer, Urs (1999), "Environmental Attitude and Ecological Behavior", Journal of Environmental Psychology, Vol. 19, No. 1: 1-19.

Kang, Kyong Ho; Stein, Laura; Heo, Cindy Yoonjoung; Lee, Seoki (2012), “Consumers' Willingness to Pay for Initiatives of the Hotel Industry", International Journal of Hospitality Management, No. 31: 564-572.

Karaca, Şükran (2013), "Tüketicilerin Yeşil Ürünlere İlişkin Tutumlarının İncelenmesine Yönelik Bir Araştırma”, Ege Akademik Bakış, C. 13, S. 1: 99-111.

Kement, Üzeyir; Çavuşoğlu, Sinan (2017), "Hafızaya Yönelik Müşteri Deneyimlerinin Müşteri Sadakatine Etkisi: Yeşil Oteller Örneği”, Uluslararası Sosyal ve Eğitim Bilimleri Dergisi, C. 4, S. 8: 172-194.

Kızıloğlu, Rüveyda; Kızılaslan, Halil; Gökçe, Ceren (2013), “Gaziosmanpaşa Üniversitesi Ziraat Fakültesi Öğrencilerinin Yeşil Gıda Ürünleri Hakkındaki Bilgi, Görüş ve Tutumları Üzerine Araştırma", Gaziosmanpaşa Bilimsel Araştırma Dergisi, S. 6: 19-30. 
Kültür ve Turizm Bakanlığı, "Çevreye Duyarlılık Kampanyası (Yeşil Yıldız)”, http://yigm.kulturturizm.gov.tr/TR,11596/cevreye-duyarlilik-kampanyasi-yesil-yildiz.html, (Erişim Tarihi 13.11.2017).

Mesci, Zeynep (2014), "Otellerin Çevreci Uygulamalarının Değerlendirilmesi: Yeşil Yıldızlı Bir Otel İşletmesinde Örnek Olay Çalışması”, Seyahat ve Otel İşletmeciliği Dergisi, C. 11, S. 1: 90-102.

Özer, Leyla; Kement, Üzeyir; Gültekin, Beyza (2015), “Genişletilmiş Planlanmış Davranış Teorisi Kapsamında Yeşil Yıldızlı Otelleri Tekrar Ziyaret Etme Niyeti", Hacettepe Üniversitesi Iktisadi ve Idari Bilimler Fakültesi Dergisi, C. 33, S. 4: 59-85.

Özgüven Tayfun, Nihan; Öçlü, Burak (2016), “Çevreci Ürünlerin Tüketicilerin Satın Alma Kararlarındaki Yeri Üzerine Bir Uygulama" Niğde Üniversitesi Iktisadi ve İdari Bilimler Fakültesi Dergisi, C. 9, S. 3: 185-198.

Yıldız, Banu; Kılıç, Sultan Nazmiye (2016), "Alman Turistlerin Çevre Bilinci ve Çevre Dostu Otel (Yeşil Otel) Algısının Davranışsal Niyetleri Üzerindeki Etkisi”, Uluslararası Sosyal Araştırmalar Dergisi, C. 9, S. 43: 2614-2623.

Yılmaz, Veysel; Arslan, Talha (2011), “Üniversite Öğrencilerinin Çevre Koruma Vaatleri ve Çevre Dostu Tüketim Davranışlarının İncelenmesi", Anadolu Üniversitesi Sosyal Bilimler Dergisi, C. 11, S. 3: 1-10.

Yılmaz, Veysel; Çelik, Halit Eray (2016), Lisrel 9.1 ile Yapısal Eşitlik Modellemesi, Ankara: Anı Yayıncılık.

Yılmaz, Veysel; Çelik, Halit Eray; Yağızer, Ceren (2009), "Çevresel Duyarlılık ve Çevresel Davranışın Ekolojik Satın Alma Davranışına Etkilerinin Yapısal Eşitlik Modeliyle Araştırılması", Anadolu Üniversitesi Sosyal Bilimler Dergisi, C. 9, S. 2: $1-14$ 
Eskişehir Osmangazi Üniversitesi IïBF Dergisi 